\title{
KAJIAN BIOAKTIFITAS DAN ANALISA KANDUNGAN SENYAWA METABOLIT SEKUNDER DARI TUMBUHAN Hornstedtia scyphifera var. fusiformis DENGAN HPLC (High Performance Liquid Chromatography)
}

\section{STUDY OF BIOACTIVITY AND ANALYSIS OF SECONDARY METABOLITE COMPOUNDS FROM THE PLANT Hornstedtia scyphifera var. fusiformis With HPLC (High Performance Liquid Chromatography)}

\author{
Adlis Santoni, Mai Efdi, Akmel Suhada \\ Jurusan Kimia, Fakultas MIPA, Universitas Andalas, Padang, Indonesia \\ Email korespondensi: adlis_1962@yahoo.com
}

\begin{abstract}
Abstrak
Hornstedtia scyphifera var. fusiformis merupakan tumbuhan endemik dari famili Zingiberaceae yang tersebar di Sumatera. Tumbuhan ini mengandung beberapa metabolit sekunder seperti fenolik, flavonoid, saponin, triterpenoid, steroid dan alkaloid. Pengujian Bioaktifitas meliputi uji antioksidan dan antibakteri. Aktivitas antioksidan ditentukan dengan metoda DPPH. Sedangkan aktivitas antibakteri diuji dengan metode difusi cakram terhadap bakteri Staphylococcus aureus (bakteri gram positif) dan Escherichia coli (bakteri gram negatif). Hasil analisa aktitifitas antioksidan dari ketiga ekstrak, diperoleh bahwa ekstrak metanol menunjukkan aktifitas antioksidan yang paling aktif dengan $\mathrm{IC}_{50}=51,8943 \mathrm{mg} / \mathrm{L}$ dibandingkan dua ekstrak lainnya. Ketiga esktrak Hornstedtia scyphifera var. fusiformis memberikan aktivitas antibakteri, selanjutnya esktrak n-heksan dan etil asetat pada konsentrasi 500 ppm memiliki zona hambat $10 \mathrm{~mm}$ terhadap bakteri Escherichia coli dan Staphylococcus aureus memiliki zona hambat 10,3 mm. Untuk mengetahui jumlah senyawa metabolit sekunder yang terkandung dalam tumbuhan ini dilakukan analisa dengan HPLC.
\end{abstract}

Kata Kunci : Hornstedtia scyphifera var. fusiformis, antibakteri, antioksidan, HPLC.

\section{PENDAHULUAN}

Penggunaan tumbuhan sebagai pilihan obat herbal telah menjadi fenomena yang universal. Sekarang ini, sebanyak $80 \%$ dari populasi dunia telah memilih obat tradisional sebagai kebutuhan perawatan kesehatan primer. Kemajuan penelitian di lapangan yang terus berkelanjutan telah memperjelas bahwa banyak spesies tanaman yang dimanfaatkan oleh masyarakat adat menjadi pilihan dalam dunia industri obat. Baru-baru ini, kebanyakan dari penelitian yang telah dilakukan terhadap obat tradisional menunjukkan bahwa beberapa obat yang diperoleh dari penyembuhan tradisional sangat efektif dan ini diperlukan pembenaran ilmiahnya. Sebagian besar terapi tradisional juga melibatkan penggunaan ekstrak tanaman sebagai dasar penyembuhan. (S, Karumaran, et al ,2016 ; Julie J. and Ernest TJ. 2012 )

Penelusuran literature ditemukan bahwa tanaman family Zingiberaceae atau lebih dikenal sebagai keluarga rimpangrimpangan terdiri dari 52 genus dan 1300 spesies banyak dimanfaatkan sebagai bahan obat. Tanaman ini pada umumnya mengandung minyak atsiri dan dari hasil uji fitokimia tanaman ini memiliki aktivitas biologis seperti antimikroba, antiokisidan, antikanker dan efek stimulan terhadap sistem imun. (( Tg. Kamazeri, T.S.A., et al 2012 ; Natta, L., Orapin, K., Krittika, N. and Pantip, B. 2008 ; . Hashim, S.E., Sirat, H.M. and Yen, K.H. 2014). 
Hornstedtia merupakan salah satu genus dari family Zingiberaceae yang memiliki aktivitas biologis antimikroba dan antijamur. Beberapa spesies Hornstedtia yang telah diteliti seperti Hornstedtia scyphifera, Hornstedtia ophiuschus, Hornstedtia striolata, Hornstedtia havilandii dan Hornstedtia phaeochana aktif terhadap bakteri Staphylococcus aureus, Escherichia coli, dan jamur Candida albican. Beberapa ekstrak Hornstedtia leonurus. Retz juga telah dilaporkan memiliki aktivitas antioksidan. (Jani, Nor Akmalazura., Ibrahim, Nordiana., dkk, 2016 ; Jani, Nor Akmalazura., Ibrahim, Nordiana., dkk, 2016, ; Lestari Titi., dkk. 2016) Hornstedtia sciphyfera var fusiformis merupakan salah satu varian dari Hornstedtia sciphyfera yang ditemukan di Sumatera Barat, Sumatera Selatan, Sumatera Utara dan Riau dalam jumlah yang cukup banyak ${ }^{9}$.Skrining aktivitas antioksidan terhadap esktrak Hornstedtia sciphyfera var fusiformis menunjukkan bahwa Hornstedtia sciphyfera var fusiformis memiliki aktivitas antioksidan. Namun tingkat kemampuan antikosi dan dan antibakteridari ektrak tanaman ini belum ada yang melaporkan termasuk identifikasi metabolit sekunder yang ada dalam tanaman tersebut.

Oleh karena itu perlu diteliti apa saja kandungan metabolit sekunder yang terdapat pada bagian akar gantung tumbuhan Hornstedtia scyphifera var fusiformis dan bagaimanakah aktivitas ekstrak metanol, etil asetat dan n-heksan dari akar gantung Hornstedtia scyphifera var fusiformis terhadap bakteri Staphylococcus aureus dan Escherichia coli dan aktivitas antioksidan dari ekstrak metanol, etil asetat, dan nheksan dari akar gantung Hornstedtia scyphifera var fusiformis serta berapa jumlah senyawa metabolit sekunder yang dominan terkandung pada akar gantung Hornstedtia scyphifera var fusiformis.

Tujuan penelitian ini adalah menentukan metabolit sekunder yang terkandung pada bagian akar gantung Hornstedtia scyphifera var fusiformis. menguji aktivitas ekstrak akar gantung Hornstedtia scyphifera var fusiformis terhadap bakteri Staphylococcus aureus dan Escherichia coli dengan metode difusi cakram, menentukan aktivitas antioksidan dengan menggunakan metode DPPH dari ekstrak-ekstrak akar gantung Hornstedtia scyphifera var fusiformis dan menentukan jumlah senyawa metabolit sekunder yang dominan terkandung pada akar gantung Hornstedtia scyphifera var fusiformis dengan HPLC. Hasil penelitian ini diharapkan dapat memberikan informasi mengenai hasil fitokimia dari akar gantung Hornstedtia scyphifera var fusiformis, aktivitas antimikroba, antioksidan dan jumlah senyawa metabolit sekunder yang dominan terkandung dari ekstrak-ekstrak akar gantung Hornstedtia scyphifera var fusiformis sehingga dapat dimanfaatkan dalam dibidang kesehatan yang bernilai ekonomis dan mudah didapat.

\section{METODE PENELITIAN}

\section{Alat dan Bahan}

Alat yang digunakan pada penelitian ini adalah corong, rotary evaporator, botol reagen, botol vial, neraca analitik, cawan petri, micropipette, gelas piala, erlenmeyer, tabung effendorf, microplate, labu ukur 10 $\mathrm{mL}$, labu ukur $100 \mathrm{~mL}$, pipet gondok $2 \mathrm{~mL}$, pipet gondok $5 \mathrm{~mL}$, pipet takar, Lampu UV ( $\lambda 254$ dan $356 \mathrm{~nm}$ ), laminar flow, dan HPLC (High Performance Liquid Chromatography)

Bahan yang digunakan pada penelitian ini adalah sampel Hornstedtia scyphifera var fusiformis Holttum, pelarut teknis yang telah didistilasi yaitu heksana, etil asetat, dan metanol. Aluminium foil, akuades, bakteri Escherichia coli dan Staphylococcus aureus, dimetilsulfoksida, gentamicyn, media Muller-Hilton agar, DPPH (1,1-difenil-2pikrilhidrazil), Whatman No. 40, alkohol $75 \%$, asam askorbat, pereaksi, pereaksi Lieberman Burchard (asam asetat anhidrat dan asam sulfat pekat), sianidin test (bubuk magnesium dan asam klorida pekat), besi (III) klorida, plat KLT dan natrium hidroksida

Bahan tumbuhan Hornstedtia scyphifera var fusiformis Holttum diperoleh dari Kawasan Padang Lua, Sumatera Barat dan Identifikasi tumbuhan dilakukan di Herbarium Universitas Andalas.

\section{Prosedur Penelitian}

Penelitian kandungan metabolit sekunder tumbuhan Hornstedtia scyphifera var fusiformis Holttum meliputi beberapa tahapan : 
Tahap survey fitokimia untuk memperoleh sampel

1. Tahap pengujian profilfitokimia untuk mengetahui kandungan metabolit sekunder, meliputi pemeriksaan senyawa metabolit sekunder dari golongan:

1) Steroid, Triterpenoid dengan pereaksi Lieberman Burchard (asam asetat anhidrat dan asam sulfat pekat).

2) Saponin dilakukan pengujian busa dengan air.

3) Flavonoid dengan pereaksi sianidin test (bubuk magnesium dan asam klorida pekat)

4) Fenolik, dengan pereaksi besi (III) klorida

5) Kumarin diuji dengan menggunakan plat KLT dan natrium hidroksida

6) Alkaloid diuji dengan pereaksi Mayer

2. Tahap pengekstraksian dengan pelarut heksan, etilasetat dan metanol untuk memperoleh kelompok senyawa metabolit sekunder berdasarkan kepolaran.

3. Tahap pengujian antibakteri dari masing-masing ekstrak dengan metode difusi cakram untuk mengetahui fraksi aktif sebagai antibakteri

4. Tahap pengujian antioksidan dari masing-masing ekstrak dengan metode DPPH untuk mengetahui fraksi aktif sebagai antioksidan.

5. Tahap penentuan jumlah senyawa metabolit sekunder dari masing fraksi aktif dengan mengunakan metoda kromatography cair bertekanan tinggi (HPLC).

\section{HASIL DAN PEMBAHASAN}

Identifikasi tumbuhan dilakukan di Herbarium Universitas Andalas (ANDA) Padang melalui surat Nomor 98/KID/ANDA/I/2017. Berat sampel yang diperoleh seberat $3 \mathrm{~kg}$.

Uji profil fitokimia dilakukan pada bagian akar gantung Hornstedtia scyphifera var. fusiformis Holttum diketahui mengandung beberapa golongan metabolit sekunder seperti fenolik, flavonoid,saponin, triterpenoid, steroid dan alkaloid.
Hasil ekstraksi sebanyak 120 gram sampel kering akar gantung Hornstedtia scyphifera var. fusiformis Holttum dengan pelarut metanol diperoleh massa ekstrak $2,040 \mathrm{~g}(1,7 \%)$, massa ektrak etil asetat $1,000 \mathrm{~g}(0,833 \%)$ dan massa ekstrak heksan $1,955(1,629 \%)$. Dari data tersebut diketahui bahwa senyawa yang bersifat polar paling banyak terdapat pada akar gantung Hornstedtia scyphifera var. fusiformis Holttum. Hal ini dapat dilihat dari massa ekstrak metanol yang memiliki massa paling besar dibandingkan esktrak lainnya.

Pengujian aktivitas antibakteri dilakukan terhadap bakteri gram positif yaitu Staphylococcus aureus dan bakteri gram negatif yaitu Escherichia coli. Sebagai pembandingnya digunakan gentamicyn dengan konsentrasi $10 \mu \mathrm{g}$ sebagai kontrol positif dan DMSO $0,1 \%$ sebagai kontrol negatif. Pengukuran dilakukan tiga kali ulangan untuk masing-masing konsentrasi dan masing-masing esktrak. Hasil uji aktifitas terhadapa bakteri dapat dilihat pada tabel 1 .

Tabel 1. Hasil Uji Aktivitas terhadap Bakteri

\begin{tabular}{|c|c|c|c|}
\hline \multirow{3}{*}{ Ekstrak } & \multicolumn{3}{|c|}{$\begin{array}{c}\text { Diameter Zona Bening (mm) } \\
\text { pada Variasi Konsentrasi }\end{array}$} \\
\hline & \multirow{2}{*}{$\begin{array}{l}\text { Konsentras } \\
\text { i (ppm) }\end{array}$} & \multicolumn{2}{|c|}{ Bakteri } \\
\hline & & $\begin{array}{c}\text { S. } \\
\text { aureus }\end{array}$ & $\begin{array}{c}\text { E. } \\
\text { coli }\end{array}$ \\
\hline \multirow{3}{*}{ Metanol } & 125 & 8,67 & 8,3 \\
\hline & 250 & 9,67 & 9 \\
\hline & 500 & 10 & 9,3 \\
\hline \multirow{3}{*}{ Etil Asetat } & 125 & 8,3 & 8,67 \\
\hline & 250 & 9 & 8,83 \\
\hline & 500 & 10,3 & 10 \\
\hline \multirow{3}{*}{ Heksan } & 125 & 9,3 & 8,67 \\
\hline & 250 & 10 & 9,67 \\
\hline & 500 & 10,3 & 10 \\
\hline \multicolumn{4}{|l|}{ Kontrol } \\
\hline$(+)$ & & 37 & 44 \\
\hline Kontrol & $1 \%$ & 7 & 6 \\
\hline
\end{tabular}

Hasil pengukuran zona bening terlihat bahwa zona hambat paling besar untuk bakteri Escherichia coli terdapat pada konsentrasi 500 ppm 9,3 mm untuk ekstrak metanol, 500 ppm $10 \mathrm{~mm}$ untuk ekstrak etil asetat dan 500 ppm 10,3 mm untuk ekstrak heksan. Sedangkan terhadap bakteri 
Staphylococcus aureus, zona hambat paling besar terdapat pada konsentrasi yang sama yaitu $500 \mathrm{ppm} 9,3 \mathrm{~mm}$ untuk ekstrak metanol, 500 ppm 10,3 mm untuk ekstrak

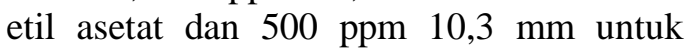
esktrak heksan.

Hasil pengujian aktifitas antioksidan dengan menggunakan metoda DPPH. Untuk masing-masing ekstrak dapat dilihat pada Gambar 1

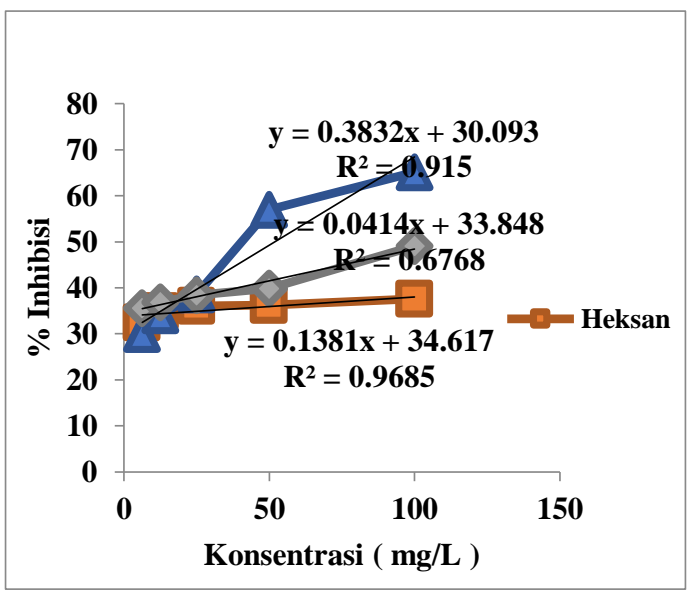

Gambar 1. Kurva Antioksidan dengan metode DPPH

Berdasarkan grafik dapat dilihat, ektrak metanol mengalami kenaikan\% inhibisi yang dratis dari konsentrasi 25 ke 50 ppm. Sedangkan ekstrak etil asetat mengalami kenaikan yang paling stabil dengan nilai $\mathrm{R}^{2}=0,968$ (mendekati 1 ) dibandingkan dengan ekstrak yang lainnya. Meskipun ekstrak n-heksan tidak menunjukkan kenaikan yang berpluktuasi seperti ekstrak metanol namun, pada esktrak $\mathrm{n}$-heksan nilai $\mathrm{R}^{2}=0,676$ sangat jauh dari nilai metanol yaitu $\mathrm{R}^{2}=0,915$.

Ekstrak metanol memiliki aktivitas antioksidan yang paling bagus diantara ekstrak yang lainnya dengan nilai $\mathrm{IC}_{50}=$ $51,8943 \mathrm{mg} / \mathrm{L}$ dan digolongkan sebagai antioksidan yang kuat. Sedangkan ekstrak etil asetat dengan $\mathrm{IC}_{50}=111,52217 \mathrm{mg} / \mathrm{L}$ digolongkan sedang dan esktrak n-heksan dengan $\mathrm{IC}_{50}=394,1463 \mathrm{mg} / \mathrm{L}$ digolongkan lemah.

Pengukuruan jumlah senyawa metabolit sekunder yang terdapat di fraksi metanol, fraksi etil asetat dan fraksi heksan dengan menggunakan metoda HPLC, belum dapat dilaporkan karena dalam proses pengerjaan.

\section{KESIMPULAN}

Berdasarkan hasil penelitian yang telah dilakukan dapat disimpulkan, bahwa golongan metabolit sekunder yang terkandung dalam bagian akar gantung Hornstedtia scyphifera var. fusiformis Holttum adalah fenolik, flavonoid, saponin, triterpenoid, steroid dan alkaloid. Semua ekstrak akar gantung Hornstedtia scyphifera var. fusiformis Holttum memiliki aktivitas terhadap Staphylococcus aureus dan Escherichia coli dan rata-rata memberikan zona hambat paling besar pada kosentrasi 500 ppm untuk masing-masing ekstrak. Aktivitas antioksidan yang paling aktif diberikan oleh ekstrak metanol dengan $\mathrm{IC}_{50}$ $=51,8943 \mathrm{mg} / \mathrm{L}$ diantara ekstrak lainnya.

\section{SARAN}

Beberapa saran untuk penelitian lanjutan sebagai berikut :

1. Untuk melakukan isolasi dan karakterisasi senyawa metabolit sekunder dari ekstrak metanol karena ekstrak ini aktif sebagai antioksidan.

2. Untuk melakukan uji aktivitas lainya seperti penentuan total fenolik dan uji toksisitas terhadap ekstrak akar gantung Hornstedtia scyphifera var. fusiformis Holttum.

3. Untuk melakukan identifikasi senyawa metabolit sekunder serta uji bioaktivitas terhadap bagian tumbuhan Hornstedtia scyphifera var. fusiformis Holttum yang lainnya 


\section{DAFTAR RUJUKAN}

Hartati, Rika. Suganda, Asep Gana. Fidrianny, Irda. Ginting, Theresia Monica. (2014). Total Flavonoid Content and Antimicrobial Properties Of Four Species Of Zingiberaceae. International Journal of Pharmacy and Pharmaceutical Sciences. ISSN- 0975-1491 Vol 6, Issue 7.

Hashim, S.E., Sirat, H.M. and Yen, K.H. (2014). "Chemical Compositions and Antimicrobial Activity of the Essential Oils of Hornstedtia havilandii (Zingiberaceae)". Natural Product Communications. 9(1): 119120

Hashim. HM, Sirat. KH, Yen. ( 2015)Antioxidant and $\alpha$-Glucosidase Inhibitory Constituents from Hornstedtia Species of Malaysia. Natural Product Community.Sep;10(9):1561-3.

Hassan,A.S. (2014). The Antibacterial Activity of Dimethyl Sulfoxide (DMSO) with and without of Some Ligand Complexes of the Transitional Metal Ions of Ethyl Coumarin against Bacteria Isolate from Burn and Wound Infection. Journal of Natural Science Research. Vol4, No 19. Hal 106-111.

Jani, Nor Akmalazura., Ibrahim, Nordiana., dkk, ( 2016) Antimicrobial and Antioxidant Activities of Hornstedtia leonurus Rezt. Extract, Journal of Science and Technology.

Julie J. and Ernest TJ. (2012). Evaluation of Antioxidant Potential of Rhizome Extyracts of Two Species of Alpinia Roxb. (Zingiberacea). International Research Journal of Pharmacy. 3(4) : 402-404.

Kalita, Sanjeeb, Kumar, Gaurav, Karthik, Loganathan, Rao, Kokati Venkata Bhaskara. (2014) In vitro antioxidant and DNA damage inhibition activity of aqueous extract of Lantana camara L. (Verbenaceae) leaves. Asian Pacific Journal of Tropical Medicine. 1675-1679

Kamazeri, T.S.A., Abd Samah, O., Taher, M., Susanti, D. and Qaralleh, H. (2012). "Antimicrobial Activity and Essential Oils of Curcuma aeruginosa, Curcuma mangga, and Zingiber cassumunar from Malaysia". Asian
Pacific Journal of Tropical Medicine. 202-209

Karumaran., S, Nethaji., R, Rajakumar., (2016) Antimicrobial and antioxidant activity of leaf extracts of Aegle marmelos, Advances in Applied Science Research, 7(3):205-208.

Khalaf, N. A. (2008). Antioxidant Activity of Some Common Plants, Faculty of Pharmacy and Medicinal Sains, Jordan, 32, Hal 51-55.

Lestari Titi., dkk. (2016) Studi Morfometrik Hornstedtia leonurus (J.Koenig) Retz. (Zingiberaceae) dan Kerabat Dekatnya dalam Tribe Alpiniae di Sumatera Barat, Jounal Biologi Universitas Andalas, (4).

Molyneux, P.(2004) The use of stable free radical diphenylpicryl-hydrazyl (DPPH) for estimazing antioxidant activity. Songklanakarin J Sci Technol, 26:211219

Natta, L., Orapin, K., Krittika, N. and Pantip, B. (2008). "Essential Oil from Five Zingiberaceae for Anti Food-borne Bacteria”. International Food Research Journal. 15(3): 337-346.

Nurainas., Syamsuardi., Rabin, Adrianis., Distribusi Hornstedtia Retz. (Zingiberaceae) di Sumatera, Universitas Andalas.

Shekhar, T, C, Anju, G ( 2014). Antioxidant activity by DPPH Radical Scavenging Method of Agretum conyzoides Linn. Leaves, American Journal of Ethnomedicine, Vol 1, No 4, 244-249

Wadhwani,T. Desai,K. Patel,D. Lawani,D. Bahaley,P. Joshi,P. Kothari,V. (2008). Effect of various solvents on bacterial growth incontext of determining MIC of various antimicrobials. The Internet Journal of Microbiology. Vol 7, No 1, Hal 1-6.

Wanjek, C. (2001). Mixed messages: antioxidants may in some cases do more harm than good. The Washington Post, 7 Aug, p HE01. 